\title{
MELACAK EKSISTENSI KEARIFAN LOKAL DALAM KEBIJAKAN PENGEMBANGAN PARIWISATA KABUPATEN SIAK DI ERA GLOBALISASI
}

\author{
Zulfa Harirah $^{1^{*}}$, Wazni Azwar ${ }^{1}$, Isril ${ }^{1}$ \\ ${ }^{1}$ Universitas Riau, Indonesia \\ "e-mail: zulfaharirahms@lecturer.unri.ac.id
}

\begin{abstract}
Abstrak
Penelitian ini dimaksudkan untuk melihat eksistensi kearifan lokal dalam kebijakan pariwisata di Kabupaten Siak, Provinsi Riau. Ide dasar tulisan ini berangkat dari kegelisahan dalam mengamati fenomena pengembangan pariwisata berbasis kearifan lokal yang mulai ditinggalkan. Kearifan lokal dianggap kuno dan tidak menarik menyebabkan tidak banyak daerah yang mengembangkan pariwisata berbasis kearifan lokal. Terlebih dalam era globalisasi, kekhawatiran akan pudarnya kearifan lokal yang dikelilingi oleh budaya barat menjadi tantangan tersendiri bagi eksistensi kearifan lokal. Namun berbeda yang terjadi di Kabupaten Siak, kearifan lokal justru menjadi kekuatan dalam kebijakan pariwisata. Sehingga menjadi penting untuk melacak lebih jauh penguatan kearifan lokal dalam kebijakan pariwisata di Kabupaten Siak. Penelitian ini merupakan penelitian kualitatif melalui pendekatan studi kasus. Penelitian ini dilakukan melalui teknik observasi, wawancara mendalam, dokumentasi. Data yang sudah dikumpulkan kemudian dianalisis dengan mengatur, mengurutkan, mengelompokkan, memberi kode/tanda, dan mengkategorikan data sehingga diperoleh temuan yang sesuai dengan masalah yang ingin dijawab. Hasil penelitian menunjukkan bahwa secara formalitas kearifan lokal dalam pengembangan pariwisata di Kabupaten Siak masih terbukti eksis. Namun secara substansi, nilai-nilai kearifan lokal mulai mengalami perubahan seiring dengan tidak dilibatkannya Lembaga Adat Melayu dalam pengembangan pariwisata di Kabupaten Siak. Secara konteks, masyarakat mendukung pelaksanaan kebijakan pengembangan pariwisata berbasis budaya melayu. Sedangkan pada sisi input, proses dan produk menunjukkan bahwa pengembangan pariwisata berbasis kearifan lokal masih memerlukan perbaikan pada sisi kualitas SDM, koordinasi antar lembaga dan pelestarian nilai budaya.
\end{abstract}

Kata kunci: Kebijakan Pariwisata; Kearifan Lokal; Budaya Melayu; Kabupaten Siak

\begin{abstract}
This research is intended to see the existence of local wisdom in tourism policy in Siak Regency, Riau Province. This paper's basic idea departs from anxiety in observing the phenomenon of the development of tourism based on local wisdom that is becoming obsolete. Local wisdom is considered old-fashioned, unattractive, and left behind, causing not many regions to develop tourism based on local wisdom. Especially in the era of globalization, concerns about the fading of local wisdom surrounded by western culture and other cultures become a challenge for local wisdom. Nevertheless, what is different is in Siak Regency, local wisdom, namely Malay culture, has become a strength in tourism policy. It becomes crucial to track further the strengthening of local wisdom in tourism policy in Siak Regency. This research is qualitative research through a case study approach. This research was conducted through observation techniques, in-depth interviews, documentation. The data that has been collected is then analyzed by arranging, sorting, classifying, coding/marking, and categorizing the data so that findings are obtained following the problem to be answered. The results showed that formally local wisdom in tourism development in Siak Regency
\end{abstract}


Zulfa Harirah, Wazni Azwar, Isril | Melacak Eksistensi Kearifan Lokal Dalam Kebijakan Pengembangan Pariwisata Kabupaten Siak Di Era Globalisasi

still proved to exist. However, in substance, the values of local wisdom began to change along with the non-involvement of the Malay Customary Institution in the development of tourism in Siak Regency. In context, the community supports the implementation of Malay culture-based tourism development policies. While on the input side, the process and product show that the development of tourism based on local wisdom still needs improvements in human resource quality, coordination between institutions, and cultural values preservation.

Keywords: Tourism Policy; Local Culture; Malay Culture; Siak Regency

This is an open access article under the CC BY-SA license.

Copyright @ 2021 by Author. Published by Universitas Pendidikan Ganesha.

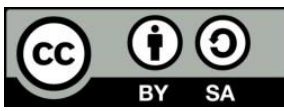

\section{PENDAHULUAN}

Pariwisata yang berbasis kearifan lokal telah menjadi komoditas promosi wisata yang laris manis dijual kepada masyarakat sebagai daya tarik objek wisata. Kearifan lokal yang mampu dikemas secara apik, digadang-gadang mampu membentuk local branding suatu tempat hingga meningkatkan jumlah wisatawan. Karena tidak dapat dipungkiri bahwa dunia pariwisata merupakan salah satu penyumbang devisa terbesar bagi negara. Sehingga sudah selayaknya pengembangan pariwisata mendapat atensi lebih, terutama pariwisata berbasis nilai-nilai lokal yang mampu menjangkau dimensi kultural, politik dan bisnis (Usman, 2003).

Salah satu destinasi wisata yang memiliki daya pikat pariwisata yang indah dan tetap mempertahankan kearifan lokal adalah Kabupaten Siak, Provinsi Riau. Sebagai daerah yang kental dengan nilai-nilai melayu, maka Kabupaten Siak tidak mau ketinggalan dalam mengembangkan wisata berbudaya melayu. Atraksi utama yang dimunculkan oleh objek wisata di Kabupaten Siak digarap sejalan dengan visi Provinsi Riau yaitu "Terwujudnya pariwisata yang mendukung ekonomi daerah dan lestarinya budaya melayu sebagai kebijakan pembangunan di Provinsi Riau". Oleh sebab itu program unggulan pariwisata yang dikembangkan adalah pariwisata berbasis budaya melayu.

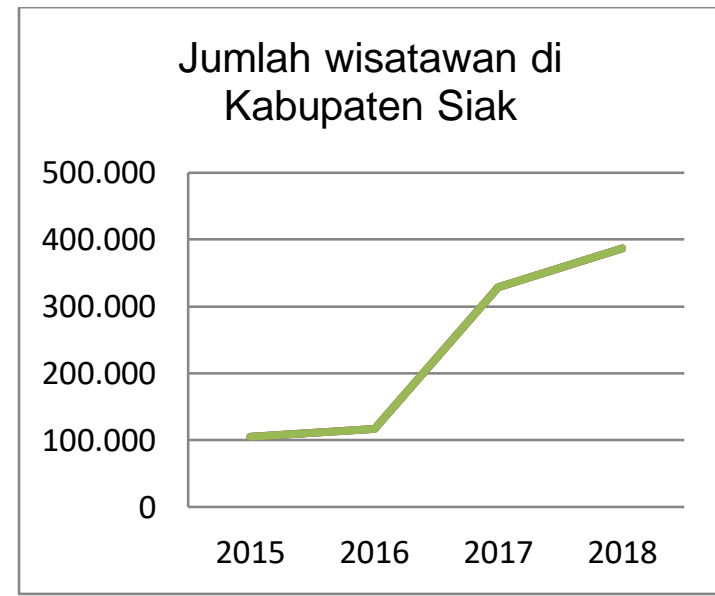

Gambar 1. Jumlah Wisatawan Sumber: BPS Kabupaten Siak

Kekayaan kultural Kabupaten Siak menjadi daya tarik tersendiri bagi para wisatawan. Hal itu terlihat dari jumlah wisatawan yang datang di Kabupaten Siak selalu bertambah. Interaksi antar pelaku pariwisata merupakan modal utama dalam pengembangan parisiwata berbasis budaya melayu. Pada dasarnya konsep wisata berbudaya melayu merupakan pengintegrasian nilai keislaman kedalam seluruh aspek kegiatan wisata. Tidak dapat dipungkiri bahwa budaya melayu 
Zulfa Harirah, Wazni Azwar, Isril | Melacak Eksistensi Kearifan Lokal Dalam Kebijakan Pengembangan Pariwisata Kabupaten Siak Di Era Globalisasi

menjadi budaya yang begitu erat disandingkan dengan agama Islam. Pariwisata berbudaya melayu dijewantahkan dalam berbagai sektor, seperti busana melayu, permainan rakyat, rumah makan, transportasi, dll. Nilai halal dan haram menjadi tolak ukur utama bagi setiap pelaku pariwisata.

Saat ini Kabupaten Siak sedang gencar mempromosikan local brandingnya yaitu "Siak the truly Malay". Hal ini mengisyaratkan bahwa jika ingin mengetahui budaya melayu di Provinsi Riau, maka Kabupaten Siak adalah jawabannya. Sebagai pusat sejarah dan budaya Melayu di Provinsi Riau, Kabupaten Siak telah menjelma menjadi destinasi wisata budaya Indonesia. Melalui slogan "Siak the Truly Malay" yang digaungkan menjadi upaya untuk menjiwai grand design pengembangan budaya melayu di Provinsi Riau.

Keberanian Pemerintah Daerah Kabupaten Siak untuk mempatenkan slogan "Siak the Truly Malay" mengacu pada banyak wisata budaya melayu yang dapat ditemui di Kabupaten Siak. Pertama, situs sejarah melayu yang berdiri megah di Kabupaten Siak adalah Istana Siak yang menjadi simbol kebesaran bangsa melayu. Istana Kerajaan Siak menjadi bukti berbagai peninggalan kerajaan dan arsitektur melayu pada bangunan istana Siak. Kedua, jembatan Tengku Agung Sultanah Latifah menjadi ikon baru destinasi wisata yang mengintegrasikan Kecamatan Mampuran dan Kecamatan Siak Sri Indrapura diatas sungai Siak. Ketiga, Balai Kerapatan Adat Siak yang memiliki gaya arsitektur khas melayu. Balai ini memiliki nilai sejarah yang kuat karena merupakan tempat penobatan para raja yang menjadi simbol budaya politik dan kepemimpinan melayu. Keempat, Makam Koto Tinggi yang letaknya berada di sebelah timur Istana Siak. Makam ini merupakan kompleks pemakaman raja-raja kesultanan Siak dan menjadi bukti nyata hadirnya kerajaan Siak pada masa lampau. Kelima, Masjid Raya Syahabuddin juga menjadi salah satu daya tarik dan point branding Kabupaten Siak. Kemudian yang terakhir terdapat kapal Kato Kesultanan Siak yang merupakan kendaraan pada masa Kesultanan Siak.

Selain wisata yang berbasis arsitektural bersejarah, Kabupaten Siak juga memiliki wisata alam yang memuat nilai budaya melayu dan dapat menjadi pilihan wisatawan antara lain yaitu Taman Hutan Raya Sultan Syarif Kasim, Ekowisata Mangrove Mangkapan, Taman Air Mancur Zapin, Taman Wisata Danau Zamrud dan Susur Sungai Menpura. Dari keseluruhan objek wisata yang ada di Kabupaten Siak menunjukkan bahwa menghidupkan nilainilai lokal merupakan tindakan terbaik agar kearifan lokal tidak dirampas oleh kaum pemodal yang mengejar nilai materil. Menjaga struktur tatanan nilai di tengah gemuruh arus perubahan globalisasi menjadi tahapan untuk melakukan defense terhadap lajunya informasi yang memberi efek domino bagi suatu daerah.

Harus diakui bahwa sektor pariwisata berbasis kearifan lokal menemui tantangannya tatkala arus globalisasi membuka kran bagi masuknya budaya barat dan persaingan pariwisata global. Kekhawatiran akan masuknya budaya barat yang tidak sesuai dengan budaya Indonesia diperparah dengan kekhawatiran terkikisnya nilai-nilai budaya lokal. Globalisasi menjadi fenomena yang tidak terelakkan dan bukan tidak mungkin akan mengancam eksistensi budaya lokal. (Mubah, 2011) Bagaikan dua mata koin yang berbeda, kemajuan perkembangan perkotaan yang semakin modern terdapat kontradiksi dengan kehidupan masyarakat asli yang terpinggirkan akibat tergusurnya "kantong kebudayaan". 
Sesuai dengan amanat UndangUndang No 10 Tahun 2009 tentang kepariwisataan bahwa kepariwisataan ini diperlukan untuk mendorong pemerataan, kesempatan berusaha, memperoleh manfaat dan tangguh dalam menghadapi tantangan lokal, nasional, maupun global. Tidak dapat dinafikkan bahwa globalisasi juga membawa banyak keuntungan bagi pariwisata dalam negeri. Komunikasi antar bangsa yang terjalin dengan baik dapat menjadi media promosi pariwisata. Memperkenalkan identitas negara dengan beragam budayanya dapat membawa pariwisata berbasis kearifan lokal mendunia. Harus diakui bahwa pariwisata saat ini bukan hanya sekedar ladang bisnis tetapi juga sebagai ajang memperkenalkan diri di kancah internasional dan dituntut untuk mampu bersaing.

Disisi lain, ancaman globalisasi terhadap eksistensi budaya lokal semakin menunjukkan taringnya tatkala saat ini kita melihat fenomena yang menunjukkan bahwa budaya lokal seolah-olah telah tergantikan oleh budaya global. Misalnya saja konser musik k-pop yang lebih digandrungi anak muda dibandingkan dengan melihat pementasan wayang atau pertunjukan tradisional lainnya. Secara faktual dapat juga dilihat bahwa wisata belanja seperti mall lebih banyak diminati daripada pengunjung museum. Ini menunjukkan bahwa wisata budaya memiliki tantangan besar untuk menarik hati para wisatawan. Maka bukan tidak mungkin semakin meningkatnya jumlah produk modernisme justru semakin menyebabkan budaya yang berbau tradisi semakin ditinggalkan karena dianggap kuno dan tidak kekinian.

Masuknya arus globalisasi ke Indonesia memaksa sektor pariwisata Indonesia untuk berbenah. Ditambah lagi, pusaran arus globalisasi menuntut Pariwisata memulai era Tourism 4.0 lengkap dengan SDM unggul dibidang pariwisata, infrastruktur, dan penggunaan teknologi modern. Oleh sebab itu, tuntutan untuk menghasilkan kreasi baru mutlak dilakukan demi memuaskan para wisatawan. Kondisi ini pada akhirnya menimbulkan dilema antara mengamini potensi pasar dengan nilai global atau tetap mempertahankan nilai-nilai kearifan lokal.

Pada dasarnya pengembangan pariwisata saat ini telah mengalami pergeseran kearah pariwisata yang berbasis komunitas dan bersandar pada nilai kearifan lokal. Namun disisi lain, pembangunan pariwisata tidak akan pernah terlepas dari tuntutan dan mobilitas regional, nasional hingga global. Dalam era globalisasi saat ini, semboyan "think globally act locally" dapat menjadi jurus ampuh menghadapi tantangan. Dimana berfikir secara global namun bertindak secara lokal akan menjadi benteng diri agar tidak terbawa arus kemajuan yang bisa saja menyesatkan.

Kenyataan dalam melakukan upaya pelestarian budaya di era globalisasi masih menyisahkan banyak kendala. Secara kasat mata barangkali pariwisata meningkatkan jumlah wisatawan asing namun disisi lain ada kearifan lokal yang mulai tergerus. Salah satu contoh terjadi di Bali, dimana sektor pariwisata sudah terbukti mampu mendongkrak dan menjadi penggerak roda perekonomian masyarakat Bali. Namun disisi yang lain, dampak dari pengembangan pariwisata tersebut menyebabkan Bali menjadi bebas. (Balquini, 2010). Dilihat dari sisi internal, rasa cinta dan bangga terhadap budaya asli masih rendah. Hal ini menjadi salah satu penyebab kearifan lokal tidak dapat bersaing dengan budaya lain. Sedangkan sisi eksternal banyak dipengaruhi oleh media dan semakin merabahnya budaya modern dari luar 
yang merasuk kek sendi-sendi masyarakat.

Pariwisata berbasis sejarah dan budaya berbeda dengan wisata yang menyuguhkan panorama perairan laut kepulauan bak sepenggal surga dunia. Destinasi wisata dengan sejuta keindahan alam baik dataran maupun lautan selalu menjadi primadona. Hal ini tentu saja menyisakan pekerjaan rumah bagi wisata berbasis sejarah dan budaya lokal untuk segera berbenah. Ditengah pusaran arus globalisasi yang menuntut serba canggih dan menarik, maka wisata sejarah dan budaya bisa jadi tidak menarik jika tidak dikelola dengan bijak. Oleh sebab itu, penelitian ini berhasrat untuk melacak eksistensi kearifan lokal pada kebijakan pariwisata di Kabupaten Siak ditengah arus globalisasi. Perlu ditelisik lebih dalam bagaimana sesungguhnya eksistensi dari budaya melayu itu sendiri bertahan dan menjadi kekuatan dalam merumuskan kebijakan pariwisata Kabupaten Siak.

Dengan demikian, Penelitian ini hendak mengeksplorasi dan menganalisis kebijakan pariwisata di Kabupaten Siak yang berbasis kearifan lokal yaitu budaya melayu. Terutama untuk mengetahui eksistensi kearifan lokal yang bertarung dengan budayabudaya lain di era globalisasi dalam kebijakan pariwisata Di Kabupaten Siak. Sehingga hasil penelitian ini bermanfaat untuk memperkaya studi mengenai kebijakan sektor publik, studi kelembagaan daerah dan masalahmasalah pemerintahan serta menambah pengetahuan masyarakat dan pemerintahan daerah serta stakeholder pembangunan lainnya terkait kebijakan publik yang memfasilitasi terjaganya kearifan lokal.

Dalam upaya menemukan jawaban penelitian, maka teori yang digunakan sebagai pisau analisis adalah evaluasi kebijakan model CIPP. Dalam proses evaluasi kebijakan publik tentu tidak dapat dilepaskan dari standar penilaian tertentu yang menjadi pedoman dalam mengevaluasi kebijakan (Subarsono, 2005). Evaluasi memberi informasi yang valid dan dapat dipercaya mengenai kinerja kebijakan, yaitu seberapa jauh kebutuhan, nilai, dan kesempatan telah dapat dicapai melalui tindakan publik (Nurgoho, 2008). Dapat dikatakan bahwa evaluasi merupakan tahap akhir dari proses kebijakan sebelum kebijakan dihentikan atau dikaji ulang (Abidin, 2012).

Proses tawar-menawar (bargaining) antaraktor pembuat kebijakan dengan menggunakan kebebasan dan kewenangannya bukan hal yang tabuh untuk dilakukan, dan bahkan kebebasan dan kewenangan tersebut sering disalahgunakan bukan untuk menyinkronkan kepentingan rakyat, melainkan untuk kekuasaan (power) (Anggara, 2014). Awalnya model CIPP digunakan untuk mengevaluasi program pendidikan. Namun hingga kini, model CIPP telah digunakan untuk menganalisis berbagai bidang kajian. Ruang lingkup model CIPP terdiri atas 4 komponen, yaitu context, input, process, and product seperti yang dijelaskan pada Gambar 2.

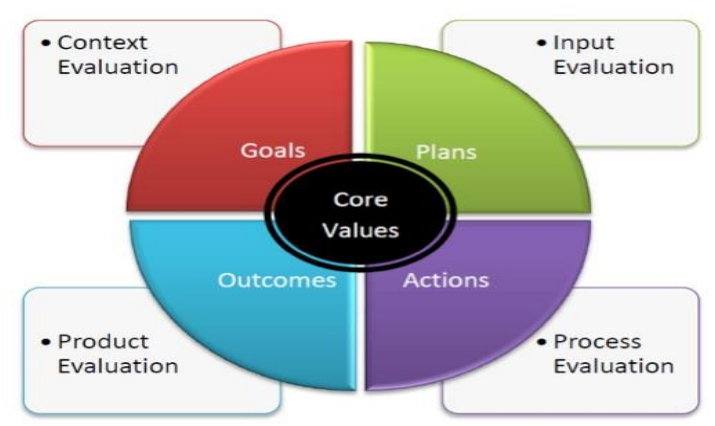

Gambar 2.

Komponen Model Evaluasi CIPP

Sumber: (Stufflebeam, 2003)

Pertama, Context Evaluation. Evaluasi konteks merupakan gambaran 
Zulfa Harirah, Wazni Azwar, Isril | Melacak Eksistensi Kearifan Lokal Dalam Kebijakan Pengembangan Pariwisata Kabupaten Siak Di Era Globalisasi

situasi atau latar belakang yang mempengaruhi tujuan dan strategi yang digunakan dalam suatu program kebijakan. Dengan kata lain bahwa mengevaluasi konteks kebijakan maka akan berkaitan dengan lingkungan dan kondisi aktual yang terjadi. Sehingga evaluasi konteks menggambarkan secara jelas mengenai tujuan program yang ingin dicapai.

Kedua, Input Evaluation. Evaluasi input bertujuan untuk memberikan informasi dalam memanfaatkan sumberdaya yang dimiliki. Melalui evaluasi input, maka akan diperoleh gambaran mengenai sumber daya dan strategi yang digunakan untuk mencapai tujuan. Informsi tersebut akan bermanfaat dalam menunjang terwujudnya efektifitas sebuah program kebijakan. Evaluasi input memberikan gambaran dalam menentukan sumber daya yang ada, alternatif yang dapat diambil, rencana serta strategi yang harus digunakan. Komponen evaluasi masukan ini terdiri atas: a) sumberdaya manusia, b) sarana dan prasarana serta sumberdaya pendukung lainnya, c) dana atau anggaran, d) prosedur dan aturan yang diperlukan.

Ketiga, Process Evaluation. Evaluasi proses merujuk pada kegiatan yang dilakukan program, siapa yang bertanggung jawab, serta sebagai implementasi strategi yang telah ditetapkan. Evaluasi ini menjadi penting mengingat tujuannya untuk membantu menemukan kelemahan sebuah program dan memperbaiki keadaan yang ada. Fokus utama dalam mengevaluasi proses bersentuhan dengan kesesuaian antara rencana program kebijakan dengan implementasi kebijakan, kehandalan stakeholders kebijakan dalam melaksanakan program, sarana dan prasarana digunakan secara maksimal atau tidak, serta mengidentifikasi hambatan-hambatan dalam implementasi program kebijakan.
Keempat, Product Evaluation. Merupakan "judgement outcomes" yang berkaitan dengan context, input dan process. Evaluasi product diarahkan untuk melihat perubahan yang terjadi dan mengukur keberhasilan mencapai tujuan. Fokus utama dari evaluasi produk adalah a)hasil-hasil yang diperoleh, b) sejauhmana kebutuhan sudah terpenuhi, c) manfaat yang diperoleh dari program kebijakan, d) impact dari sebuah program kebijakan.

Dengan demikian, penelitian ini hendak mengeksplorasi dan menganalisis kebijakan pariwisata di Kabupaten Siak yang berbasis kearifan lokal yaitu budaya melayu. Terutama untuk mengetahui eksistensi kearifan lokal yang bertarung dengan budaya-budaya lain di era globalisasi dalam kebijakan pariwisata Di Kabupaten Siak.

\section{METODE}

Penelitian ini berfokus pada upaya untuk menganalisis eksistensi kearifan dalam kebijakan pariwisata. Penelitian ini dilakukan di Kabupaten Siak dengan alasan bahwa Kabupaten Siak merupakan salah satu wilayah yang sangat gencar mempromosikan daerah sebagai daerah wisata melayu. Penelitian ini merupakan penelitian kualitatif yang lebih mengutamakan penggunaan logika induktif dimana kategorisasi dilahirkan dari perjumpaan peneliti dengan informan di lapangan atau data-data yang ditemukan. Menurut Gubrium dan Hostlein (1992) metode kualitatif adalah cara mengkaji kualitaskualitas kehidupan keseharian yang mencakup rentang luas, yaitu from life's action and naratives to its sign, circumstances and sense of reality (Suyanto \& Sutinah, 2005). Melalui pendekatan studi kasus, penelitian ini berusaha menggambarkan, menjelaskan dan menganalisis fenomena, peristiwa, aktivitas, kepercayaan, persepsi dan 
Zulfa Harirah, Wazni Azwar, Isril | Melacak Eksistensi Kearifan Lokal Dalam Kebijakan Pengembangan Pariwisata Kabupaten Siak Di Era Globalisasi

pemikiran secara individual dan kelompok.

Dalam penelitian ini dikumpulkan berbagai data yang diperoleh melalui pengamatan yang seksama, mencakup deskripsi dalam konteks yang detail disertai hasil wawancara yang mendalam dan hasil analisis dokumen. Data penelitian ini terdiri dari data primer dan data sekunder. Data primer adalah data yang diperoleh langsung dari informan penelitian dengan proses wawancara yang dijadikan objek penelitian. Teknik pemilihan informan dalam penelitian ini yaitu menggunakan teknik purposive. Penelitian ini dilakukan melalui teknik observasi, wawancara mendalam, dokumentasi.

Hal terakhir yang dilakukan adalah analisis data terhadap temuan substantif maupun temuan formal. Analisis data menjadi sebuah kegiatan yang dilakukan untuk mengatur, mengurutkan, mengelompokkan, memberi kode/tanda, dan mengkategorikan data sehingga diperoleh temuan yang sesuai dengan masalah yang ingin dijawab. Analisis data dalam penelitian kualitatif adalah proses mencari dan menyusun secara sistematis data yang diperoleh dari hasil wawancara, catatan lapangan dan dokumentasi, dengan cara mengorganisasikan data ke dalam kategori, menjabarkannya ke dalam unitunit, melakukan sintesa, menyusun ke dalam pola, memilih mana yang penting untuk dipelajari dan membuat kesimpulan. Dengan begitu, data akan mudah dipahami oleh peneliti sendiri maupun orang lain (Sugiyono, 2006).

\section{HASIL DAN PEMBAHASAN}

Kajian mengenai kearifan lokal dan pariwisata bukanlah hal baru yang belum pernah diteliti sebelumnya. Beberapa penelitian lain telah berupaya memetakan keterkaitan antara kearifan lokal dan pengembangan pariwisata.
Harus diakui bahwa budaya dan kearifian lokal yang dimiliki oleh suatu daerah dapat menjadi potensi unggulan pariwisata (Rahmi, 2016) . Setiap daerah tentu saja berkepentingan dalam memajukan daya tarik wisata karena mampu menggerakkan ekonomi lokal yang bersifat kerakyatan (George, 2010). Pada saat yang sama, merawat kearifan lokal juga menjadi upaya untuk menjaga aset-aset wisata (Bullen \& Love, 2011).

Di Kabupaten Siak, pengembangan pariwisata diarahkan pada penguatan nilai-nilai budaya melayu sebagai salah satu bentuk merawat kearifan lokal. Pertama, secara konteks, pengembangan pariwisata di Kabupaten Siak mengacu pada lingkungan masyarakat yang masih menjunjung nilai-nilai budaya melayu.

Sebuah kebijakan publik niscaya membentuk lingkungannya sebagai sebuah sistem, baik sosial, ekonomi politik dan budaya. Hubungan timbal balik antara kebijakan dan lingkungan terjadi ketika kebijakan menyalurkan masukannya pada lingkungan sekitar dan pada saat yang sama atau saat yang lain lingkungan juga membatasi perilaku pembuat kebijakan. Ini menunjukkan simbiosis mutualisme antara kebijakan dan lingkungan sekitar. Menurut Robert Eyestone, kebijakan publik merupakan hubungan suatu unit pemerintahan dengan lingkungannya (Alam, 2012).

Pada dasarnya, pariwisata berbasis budaya cenderung menjual karakteristik khas dari bentuk dan fungsi bangunan bersejarah. Namun persoalan di beberapa kawasan wisata berbasis cagar budaya adalah masalah kerusakan fisik. (Sahubawa, Antariksa, \& F.Usman, 2010) Selain faktor kondisi fisik, kondisi lingkungan di sekitar tempat wisata juga berpengaruh dalam mendukung daya tarik wisata (Shankar, 2015). Sehingga keterlibatan semua stakeholders baik Pemerintah, Swasta dan masyarakat 
Zulfa Harirah, Wazni Azwar, Isril | Melacak Eksistensi Kearifan Lokal Dalam Kebijakan Pengembangan Pariwisata Kabupaten Siak Di Era Globalisasi

mutlak dibutuhkan dalam pengembangan wisata (Caraba, 2011).

Pariwisata di Kabupaten Siak berada dalam lingkungan masyarakat yang mendukung. Sebab mayoritas masyarakat di Kabupaten Siak adalah melayu. Sehingga tepat jika kebijakan pengembangan pariwisata dengan slogan "the truly of Malay" karena faktor sejarah juga dukungan dari masyarakat setempat. Setiap ada even pariwisata, masyarakat akan antusias menjadi ambassador pariwisata yang mempromosikan kegiatan. Ini menjadi salah satu bentuk dukungan dari lingkungan sekitar terhadap kebijakan pengembangan pariwisata di Kabupaten Siak.

Pentingnya kebijakan publik yang melindungi "kekhasan kearifan lokal" perlu dilakukan agar tidak berbenturan dengan local wisdom (Sumada, 2017). Kultur masyarakat memiliki pengaruh terhadap perkembangan wisata di daerahnya. Pengembangan pariwisata yang baik tidak hanya berorientasi pada keuntungan semata, melainkan perlu menaruh perhatian besar pada budaya setempat (Karim, 2010).

Kedua, dari aspek input menunjukkan bahwa sumber daya yang mendukung pelaksanaan pengembangan pariwisata masih belum memadai. Diketahui bahwa hingga saat ini sumber daya manusia bidang kepariwisataan masih terbatas jumlahnya. Hal ini tentu saja berpengaruh terhadap pelaksanaan program bidang pariwisata.

Hal yang menjadi catatan penting dibagian input adalah terkait koordinasi antar stakeholders yaitu Dinas Pariwisata, Pemerintah Daerah dan Lembaga Adat Melayu Riau Kabupaten Siak tidak terjalin dengan harmonis. Sejak tahun 2017, Lembaga Adat Melayu Riau Kabupaten Siak tidak dilibatkan secara intensif dalam pengembangan pariwisata di Kabupaten Siak. Pengelolaan pariwisata telah dilakukan secara penuh oleh Dinas Pariwisata Kabupaten Siak. Kenyataan ini tentu saja menyiratkan bahwa pengelolaan pariwisata yang berbasis budaya melayu justru meninggalkan LAM sebagai ujung tombak budaya melayu.

Selain mengenai sumber daya manusia dan koordinasi antar stakeholders, sarana prasarana juga menjadi salah satu penunjang keberhasilan pelaksanaan pengembangan pariwisata berbasis budaya melayu. Keterlibatan seluruh elemen masyarakat dalam menghargai seni-budaya menjadi stimulan yang dapat mengimbangi kemajuan teknologi (Susilo \& Soeroso, 2009).

Di Kabupaten Siak sendiri, sarana dan prasarana di daerah tujuan wisata masih terbatas. Meskipun sudah menunjukkan kondisi yang membaik, namun masih minim pada pemanfaatan kemajuan teknologi komunikasi dan informasi sebagai sarana pemasaran dan promosi pariwisata.

Persaingan dalam menciptakan destinasi wisata yang mampu mendatangkan wisatawan dan investor menjadi tuntutan pasti di pasar global. Kabupaten Siak dihadapkan pada situasi belum optimalnya input yang mendukung kesiapan untuk bersaing dipasar global. Rendahnya sumberdaya manusia dibidang pariwisata, lemahnya koordinasi antar stakeholders serta minimnya sarana dibidang komunikasi menjadi tantangan serius dalam mengembangkan pariwisata berbasis budaya melayu di era globalisasi.

Ketiga, aspek proses. Persaingan di era global yang semakin ketat menjadikan identifikasi terhadap semua faktor daya tarik wisata penting untuk dilakukan (Adi \& Saputro, 2017). Dalam pengembangan pariwisata, Kabupaten Siak mempatenkan City Branding yaitu "Siak the Truly Malay". Slogan ini menjadi salah satu tanda pengenal Kabupaten Siak di Kancah global. 
Kegiatan branding ini ditujukan untuk memperkenalkan Local Branding "Siak the Truly Malay" (Artis, 2016). Strategi dalam mempromosikan city branding tersebut tertuang dalam eventevent pariwisata berbudaya melayu (Rosadi \& Medayanti, 2019), memasarkan objek dan produk budaya melayu melalui berbagai saluran komunikasi baik situs online, media elektronik, koran lokal dan publikasi lainnya. (Salam \& Nurjanah, 2019)

Secara empirik, budaya melayu sebagai kearifan lokal yang diunggulkan masih terbukti eksis. Hingga saat ini, budaya melayu masih menjadi daya tarik wisatawan. Diakui bahwa justru budaya melayu menjadi kekhasan yang menarik minat para wisatawan untuk berkunjung dan mempelajari nilai-nilai budaya dan sejarah.

Upaya integrasi dan kontekstualisasi melayu dibidang pariwisata dikemas secara lebih kekinian. Misalnya saja di objek wisata Taman Air Mancur Zapin yang dihiasi oleh cahaya lampu yang menjadikan taman semakin mempesona di malam hari. Ditambah lagi alunan musik Zapin melayu yang menambah nuansa melayu semakin terasa. Spot foto yang ada di objek wisata juga dibuat lebih kekinian sehingga mampu menarik pengunjung termasuk kalangan anak muda.

Tidak hanya itu, berbagai event lain dan festival diadakan sebagai upaya memperkenalkan kebudayaan melayu Siak, seperti Festival Siak Bermadah, Festival Ghatib Beghanyut, Serindit Boat Race dan Tour de Siak. Festival diatas menampilkan berbagai ragam seni budaya melayu mulai dari tari zapin, lagu melayu, senandung menidurkan anak hingga menampilkan sisi religius dari masyarakat melayu Siak. Ini membuktikan bahwa eksistensi budaya melayu sebagai pemikat daya tarik wisata masih menunjukkan taringnya.
Dari sudut berbeda, keaslian budaya melayu dibidang pariwisata justru dipandang mulai tergerus. Sekretaris Lam Riau Kabuaten Siak mengakui bahwa saat ini telah terjadi pergeseran nilai-nilai budaya melayu. Sebagai pihak yang bertugas menjaga dan melestarikan nilai, norma dan adat melayu, LAMR Kabupaten Siak melihat bahwa pergeseran ini disebabkan oleh dua hal, yaitu semakin beragam penduduk yang tinggal di Kabupaten Siak dan kuatnya nilai-nilai global yang masuk.

Kearifan lokal terdiri atas dua kata, yaitu kearifan yang bermakna kebijaksanaan dan lokal yang bermakna tempat. Jadi kearifan lokal adalah gagasan yang bersifat bijaksana, bernilai baik yang tertanam dan diakui oleh masyarakat lokal tempatan. Kearifan lokal merupakan warisan budaya secara turun temurun, namun saat ini mulai pudar akibat tergerus arus budaya globalisasi (Hariyanto, 2015).

Fokus pada upaya meningkatkan jumlah wisatawan di Kabupaten Siak justru menimbulkan kealpaan dalam mempertahankan budaya melayu secara turun temurun. Misalnya saja pada festival Ghatib Beghanyut yang merupakan zikir untuk menolak bala saat ini hanya dilakukan satu kali dalam satu tahun padahal pada zaman dulu dilakukan setiap kali ada musibah. Beberapa tertib pelaksanaan Ghatib Beghanyut juga mengalami perubahan. Ditambah lagi penggunaan alat transportasi pada festival Ghatib Beghanyut yang dulunya menggunakan sampan jalo saat ini telah berubah menjadi kapal Fery. Hal ini menurut LAMR Kabupaten Siak menjadi salah satu bentuk perubahan budaya melayu yang menyesuaikan zaman.

Dalam era globalisasi, subjek kearifan lokal perlu dilindungi namun tetap mampu mengakomodasi tuntutan globalisasi ekonomi (Irianto, 2016). Kekhawatiran terhadap subjek kearifan 
Zulfa Harirah, Wazni Azwar, Isril | Melacak Eksistensi Kearifan Lokal Dalam Kebijakan Pengembangan Pariwisata Kabupaten Siak Di Era Globalisasi

lokal dapat mengalami komodifikasi budaya, dimana barang-barang budaya menjadi komoditas yang diperjual belikan melalui industri budaya sehingga dikemas berbeda dari nilai-nilai kearifan lokal aslinya (Suneki, 2012).

Hal lain yang ditemui pada tataran

praktek adalah bahwa pariwisata berbasis kearifan lokal masih sangat terbatas untuk dipromosikan. Dinas Pariwisata mengakui bahwa pelaksanaan kebijakan pengembangan pariwisata masih mengalami keterbatasan dalam hal promosi. Saat ini pemanfaatan teknologi informasi masih minim, meskipun jika dilihat dari jumlah pengunjung naik setiap tahunnya.

Harus diakui bahwa keterbatasan implementasi kebijakan disebabkan beragam faktor, mulai dari kinerja implementator belum maksimal, pendekatan top-down yang menyebabkan rendahnya partisipasi masyarakat, hingga lingkungan sosial, ekonomi dan politik yang justru menghalangi pengembangan pariwisata berbasis kearifan lokal (Jupir, 2013).

Keempat, aspek produk. Di era modernisasi saat ini, keberagaman daya tarik wisata dapat disesuaikan dengan perkembangan zaman, salah satunya adalah dengan menyajikan beragam atraksi wisata yang mendukung eksistensi dan keunikan dari sebuah tempat wisata (Rogerson \& Merwe, 2016). Atraksi wisata yang ditampilkan dapat dipadukan dengan kearifan lokal sehingga memberikan dampak positif bagi masyarakat sekitar. Sehingga diperlukan inovasi dan kreativitas yang menunjukkan kekhasan yang dapat membedakan dengan tujuan wisata daerah lainnya (Bialostocka, 2014).

Pada dasarnya, adat melayu Siak tidak lain merupakan penjelmaan nilainilai Islam dalam kehidupan sehari-hari dan akan menjadi benteng bagi budaya asing (Darussamin, 2012). Dalam upaya untuk mengevaluasi produk kebijakan dapat dimaknai bahwa branding "Siak the Truly Malay" telah berhasil mempertahankan eksistensi kearifan lokal dalam pengembangan pariwisata. Untuk mengukur keberhasilan tersebut, digunakan beberapa indikator yaitu dengan melihat hasil-hasil yang diperoleh, sejauhmana kebutuhan sudah terpenuhi, manfaat yang diperoleh dari program kebijakan, dan impact dari sebuah program kebijakan.

Pertama, dilihat dari hasilnya, data menunjukkan bahwa sejak mengusung brand "Siak the Truly Malay", pariwisata Kabupaten Siak mengalami peningkatan jumlah pengunjung. Ini jelas menjadi salah satu bukti hasil dari sebuah kebijakan untuk mengembangkan pariwisata berbasis kearifan lokal. Budaya melayu sebagai kearifan lokal mempertegas identitas Siak sebagai bekas kerajaan Melayu yang termashur sehingga sisi kemelayuan menjadi kekuatan dalam mengembangkan pariwisata berbasis kearifan lokal. Beberapa objek wisata yang ada di Kabupaten Siak menjadi bukti sejarah kebesaran kerajaan melayu Islam terbesar di Provinsi Riau, salah satunya adalah Istana Siak, Balai Kerapatan Adat Siak yang memiliki gaya arsitektur khas melayu, even Ghatib Beghanyut, festival Zapin Nusantara yang sangat kental dengan tradisi melayu, dan sebagainya.

Kedua, terkait dengan kebutuhan dalam mengembangkan pariwisata berbasis budaya perlu sikap kehatihatian. Sebab, pengembangan pariwisata di Kabupaten Siak justru meninggalkan LAMR yang menjadi ruh bekerjanya budaya melayu di Siak. Harus diakui bahwa konflik kepentingan memang merupakan sesuatu yang tidak dapat terhindarkan. Namun dalam hal pengembangan pariwisata berbasis budaya melayu keterlibatan LAMR mutlak diperlukan sebagai daya dukung 
memenuhi kebutuhan khususnya terkait budaya.

Hubungan yang kurang harmonis antara Dinas Pariwisata Kabupaten Siak dan LAMR Kabupaten Siak menjadikan pengembangan pariwisata berbasis kearifan lokal kurang sempurna. Kebutuhan akan keaslian budaya perlu dikelola sedemikian rupa oleh LAMR agar kebijakan pengembangan pariwisata berbasis kearifan lokal bukan hanya sekedar janji manis semata. Substansi dari "Siak the Truly Malay" perlu benar-benar dijaga agar pengembangan pariwisata di Kabupaten Siak tidak hanya diarahkan pada bagaimana mendatangkan banyak wisatawan namun abai terhadap penjagaan nilai-nilai budaya melayu.

Ketiga, dampak dari pariwisata berbasis budaya terlihat dari meningkatnya kunjungan pariwisata. Kondisi ini dirasakan sebagai kekuatan penggerak ekonomi masyarakat setempat. Pariwisata Siak memberikan peluang bagi masyarakat dalam melakukan perputaran ekonomi lebih cepat, khususnya bagi pelaku usaha wisata, industry kecil, hingga kuliner. Selain itu, kebijakan pengembangan pariwisata berbasis kearifan lokal seharusnya menjadi salah satu obat mujarab untuk menjaga dan melestarikan budaya.

\section{SIMPULAN DAN SARAN}

Dari penjelasan yang sudah disajikan, kesimpulan yang dapat diambil adalah bahwa eksistensi kearifan lokal pada pengembangan pariwisata dilihat dalam dua perspektif berbeda. Disatu sisi, budaya melayu menjadi daya tarik utama pada berbagai tempat pariwisata. Ditambah lagi pada aspek konteks masyarakat setempat yang mendukung pelaksanaan kebijakan pariwisata berbasis kearifan lokal. Ini menunjukkan bahwa kearifan lokal dibidang pariwisata Kabupaten Siak masih terbukti eksis ditengah tuntutan dan tantangan di era globalisasi. Disisi lain, nilai-nilai budaya melayu yang menjadi dasar dari pengembangan pariwisata justru telah mengalami perubahan. Pengembangan pariwisata yang digadang-gadang mengunggulkan budaya melayu ternyata tidak melibatkan lembaga adat melayu yang seharusnya menjadi motor penggerak utamanya. Aspek ini menjadi hal fundamental dari aspek input dan proses yang mempengaruhi keberhasilan pelaksanaan sebuah kebijakan.

\section{DAFTAR PUSTAKA}

Abidin, S. Z. (2012). Kebijakan Publik. Jakarta: Salemba Humanika.

Adi, S. W., \& Saputro, E. P. (2017). Potensi Daya Tarik Wisata Sejarah Budaya. Seminar Nasional Riset Manajemen \& Bisnis:Perkembangan Konsep dan Riset e-Business di Indonesia, (pp. 744-749). Surakarta.

Alam, S. (2012). Analisis Kebiajakan Publik: Kebijakan Sosial Perkotaan sebagai Sebuah Kajian Implementatif. Jurnal IImiah IImu Pemerintahan, 82.

Anggara, S. (2014). Kebijakan Publik. Bandung: Pustaka Setia.

Artis. (2016). Branding "Siak The Truly Malay" oleh Dinas Pariwisata Kabupaten Siak. Komunikasiana Vol 1 Nomor 1, 10-20.

Balquini, D. (2010). Pariwisata Berkelanjutan dalam Pusaran Krisisi Global. Bali: Udayana Press.

Bialostocka, O. (2014). Using the Past to Build the Future: A Critical Review of The Liberation Heritage Route Project of South Africa. Africa Insight 44(2), 94-107.

Bullen, P., \& Love, P. (2011). Adaptive reuse of Heritage Building. Structural Survey 29(5), 411-421.

Caraba, C. (2011). Communist Heritage Tourism and Red Tourism: Concept, Development and Problems. Cina Continents 1(1), 29-39. 
Zulfa Harirah, Wazni Azwar, Isril | Melacak Eksistensi Kearifan Lokal Dalam Kebijakan Pengembangan Pariwisata Kabupaten Siak Di Era Globalisasi

Darussamin, Z. (2012). Integrasi Kewarisan Adat Melayu Siak dengan Kewarisan Islam. Al-Fikra: Jurnal IImiah Keislaman Vol 11 No 2, 186204.

George, E. (2010). Intangible Cultural Heritage, ownership, copyright, and tourism. International Journal of Culture, Tourism, and Hospitality Research 4(4), 376-388.

Hariyanto, L. O. (2015). Materi Paparan Sadar Wisata dan Sapta Pesona. Bandung: Dinas Pariwisata Provinsi Jawa Barat.

Irianto, A. M. (2016). Komodifikasi Budaya di Era Ekonomi Global Terhadap Kearifan Lokal. Theologia Vol 27 Nomor 1, 213-236.

Jupir, M. M. (2013). Implementasi Kebijakan Pariwisata Berbasis Kearifan Lokal (Studi di Kabupaten Manggarai Barat). Journal of Indonesian Tourism and Development Studies Vol 1 No 1 , 28-36.

Karim, A. B. (2010). Pariwisata:Antara Tuntutan Industri dan Kearifan Lokal. Jurnal Karsa Vol XVIII No 2, 147-159.

Mubah, A. (2011). Strategi Meningkatkan Daya Tahan Budaya Lokal dalam Menghadapi Arus Globalisasi. Jurnal Fisip Unair Vol 24 No 31, 302-308.

Nurgoho, R. D. (2008). Kebijakan Publik untuk Negara-Negara Berkembang. Jakarta: PT Alex Media Komputindo.

Rahmi, S. A. (2016). Pembangunan Pariwisata dalam Perspektif Kearifan Lokal. Reformasi Vol 6 No 1.

Rogerson, C., \& Merwe, V. D. (2016). Heritage Tourism in The Global South : Development impact of the Cradle of Humankind World Heritage Site, South Africa. Local Economy 31(1-2), 234-248.

Rosadi, S., \& Medayanti, M. D. (2019). Strategi City Branding oleh Pemerintah Daerah Kabupaten Siak dalam Peningkatan Daya Tarik
Pariwisata. Jurnal Wedana Volume V No 2, 16-20.

Sahubawa, A., Antariksa, \& F.Usman. (2010). Kawasan Bersejarah Kota Tua Hindia Belanda di Bandaneira, Maluku. Arsitektur e-Journal 3(1), 1-13.

Salam, N. E., \& Nurjanah. (2019). Komunikasi Pariwisata Budaya dalam Mempromosikan City Branding "Siak the Truly Malay". Profesi Human Vol 4 No 1, 134152.

Shankar, S. (2015). Impact of Heritage Tourism in India : A case Study . International Journal of Innovative Research in Information Security (IJIRIS) 6(2), 59-61.

Stufflebeam, D. (2003). The CIPP Model for Evaluation. In T. Kellaghan, \& D. S. (eds), International Handbook of Educational Evaluation (pp. 31-62). Dorrdrecht: Kluwer Academic Publisher.

Subarsono, A. (2005). Analisis Kebijakan Publik: Konsep, Teori dan Aplikasi. Yogyakarta: Pustaka Pelajar.

Sugiyono. (2006). Metode Penelitian Kuantitatif dan R\&D. Bandung: Alfabeta.

Sumada, I. M. (2017). Peranan Kearifan Lokal dalam Perspektif Kebijakan Publik. Jurnal IImu Politik dan Komunikasi Vol VII No 1, 117-124.

Suneki, S. (2012). Dampak Globalisasi terhadap Eksistensi Budaya Daerah. Jurnal IImiah Civis Vol 21 No 1, 307-319.

Susilo, S., \& Soeroso, A. (2009). Strategi Pelestarian Kebudayaan Lokal Dalam Menghadapi Globalisasi Pariwisata. Jurnal Penelitian Bappeda Kota Yogyakarta.

Suyanto, B., \& Sutinah. (2005). Metode Penelitian Sosial: Berbagai Alternatif Pendekatan. Jakarta: Kencana.

Usman, S. (2003). Pembangunan dan Pemberdayaan Masyarakat. Yogyakarta: Pustaka Pelajar. 